\title{
Oral language teaching in English as First Additional Language at the Foundation Phase: A case study of changing practice
}

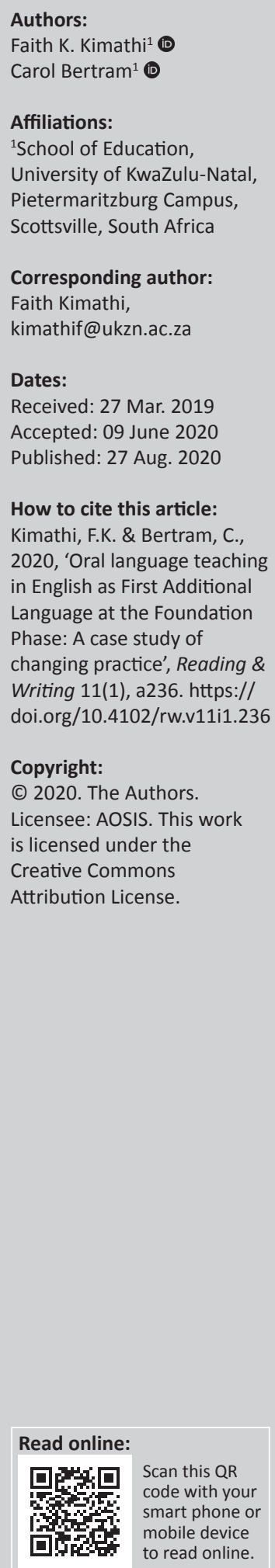

Background: Despite South Africa's huge investment in professional development, there is not a lot of research that shows that teachers change their teaching practices by attending formal interventions. This article focuses on English as First Additional Language (EFAL) and explores how one Grade 2 teacher changed her practice of oral language teaching while enrolled for an Advanced Certificate in Teaching (ACT) programme. The programme was offered to Foundation Phase teachers to improve their teaching knowledge and ultimately change their teaching practices.

Objectives: The article explores one teacher's oral language teaching and use of teacher resources in a township school. The purpose is to understand how her instructional practices changed or did not change during the 18 months while she was enrolled with the ACT programme.

Method: Data were collected over 18 months by observing six video-recorded literacy lessons, corroborated with interviews and field notes. These were analysed using principles of teaching EFAL espoused in the programme's intended curriculum.

Results: The two exemplars offered demonstrate a gradual shift in teaching of oral language and use of resources by the end of the programme. The teacher code-switched appropriately most of the time and adequately used various strategies. She created opportunities to develop learners' oral vocabulary; however, explicit sentence building was absent. Findings further revealed that the teacher's engagement with many collaborative professional development activities, school support, together with her goal-achieving character, contributed to instructional changes.

Conclusion: This study highlights that there are a number of other factors, such as the school context, the teacher's motivation and other informal learning opportunities that support teacher learning from a formal professional development intervention. It also advocates for more robust studies on how a teacher's practices change as a result of formal professional development opportunities.

Keywords: South Africa; English as first additional language; professional development programme; foundation phase; oral language; teaching change.

\section{Introduction}

In South Africa, professional development (PD) interventions are perceived as mechanisms through which teachers can acquire higher teaching credentials, improve their content knowledge and competencies of the subject they teach and ultimately improve learners' performance (Department of Basic Education \& Department of Higher Education and Training 2011). Studies on PD interventions in the last two decades indicate that despite the efforts to upgrade teachers' qualifications and provide developmental courses in various subjects, teachers seldom change their teaching practices (Adler \& Reed 2000; Bertram 2011; Fleisch 2016; Meyer \& Abel 2015). In the context of teaching language and literacy at the Foundation Phase ${ }^{1}(\mathrm{FP})$, the PD interventions have been criticised for generic designs and failure to prioritise contextual or teachers' needs (Murris 2014). Most programmes seem to apply western models which have not been tested empirically in the global south contexts (Stoffelsma 2019). Studies on PD have revealed that FP teachers' attendance at language and literacy or mathematics interventions seems to have superficial or no impact on their teaching practices among rural and township schools (Blease \& Condy 2014; Brodie, Lelliott \& Davis 2002). It is against this backdrop that this 1.First phase of formal learning (Grade R to Grade 3 ) in the South African schooling system. 
article offers insights about one FP teacher's teaching of oral language during a formal PD intervention to understand how the programme impacted on her teaching practice in a township school.

According to Curriculum Assessment Policy Statements (CAPS), teaching of language and literacy in home language (HL) and English as First Additional Language (EFAL) at the FP is associated with acquisition of listening, speaking, reading and writing skills (Department of Basic Education [DBE] 2011). The school curriculum document clearly highlights the benefits of the explicit teaching of language skills to the early graders. Scholars argue that children who do not acquire these skills by the end of Grade 3 are more likely to struggle in their future academic endeavours (Fleisch 2008; Murris \& Thompson 2016; National Education Evaluation and Development Unit [NEEDU] 2013). According to Murris (2014), CAPS is grounded on social constructivism principles but most FP teachers lack the knowledge base / or are not able to make sound pedagogical decisions to enact these principles. There is extensive research about the teaching and acquisition of EFAL reading, phonics, vocabulary and writing skills at the FP (Cilliers \& Bloch 2018; Pretorius 2014; Sibanda \& Baxen 2018; Spaull \& Hoadley 2017). However, we have limited literature on teaching oral language or the impact of PD interventions on oral language instructional practices. This case study addresses this gap.

The South African DBE has successfully implemented a range of structured pedagogical interventions such as the Gauteng Primary Literacy and Mathematics Strategy (GPLMS) in Gauteng, and Primary School Reading Improvement Programme (PSRIP) and Early Grade Reading Study (EGRS) in North West and Mpumalanga. The aim of these programmes is to fulfil the DBE's vision and mission to improve the teachers' content knowledge, increase the number of early graders who can fluently read and write in HL and EFAL, and improve the instructional practices and learners' outcomes (De Clercq \& Shalem 2015; Kotze, Fleish \& Taylor 2018). Related classroom studies in North West and Gauteng reveal that most teachers depended on traditional approaches such as rote learning or choral approaches and keep within familiar discourses during classroom interactions before these interventions (NEEDU 2014; Prinsloo et al. 2015). Teachers employ 'authoritarian roles doing most of the talking' a few individual readers or active engagement with vocabulary or writing activities (Hoadley 2012:189). Similar projects in Western Cape, Eastern Cape and KwaZulu-Natal (KZN) resonate with these findings (Spaull \& Hoadley 2017). The common consensus in these studies is that PD interventions should enable teachers to improve their teaching of language and literacy at the FP.

Internationally administered literacy tests have constantly shown poor results in the last two decades among South African learners (Spaull \& Hoadley 2017). The 2016 Progress International Reading Literacy Study (PIRLS) indicates that
$78 \%$ of South African children barely comprehend what they are reading (Howie et al. 2017). The findings echo a pre-PIRLS study which revealed that $58 \%$ of Grade 4 learners could not read fluently or decode texts in either their HL or second language (Spaull \& Hoadley 2017). These results also concur with South Africa's own Annual National Assessment (ANA) results (DBE 2016) despite the fact that the government has been spending larger amounts of its budget on education than any other African country in the last 20 years.

The DBE consistently attributes learners' poor performance in international and local assessments to a number of factors, such as poor language and literacy knowledge among FP teachers, poor teaching methods, the poor social economic status (SES) in rural or township communities and other multifaceted national challenges (DBE 2016). In particular, empirical evidence reveals that inadequately conceptualised language knowledge among FP teachers is the main cause of learners' poor outcomes in language and literacy (DBE 2016; Fleisch 2008; Pretorius 2014). In addition, what teachers learn and the impact of PD programmes on language and literacy instructional practices is still a concern in the field of research (DBE 2016; Kotze et al. 2019).

Historical arguments partially blame the poor learners' performance in language to the apartheid schooling system which offered different curricula for different races. These historical systems shaped the post-apartheid bimodal performances in which $30 \%$ of the privileged learners continue to achieve within the expected grade while $70 \%$ of learners perform poorly in rural areas. The first post-apartheid school curriculum (an outcomes-based, learner-centred approach) did not consider these contextual differences or provide a clear sequence of how to teach English language and literacy. So, many of the poorly trained FP teachers continue to struggle not only with their own English proficiency but also with implementation of the school curriculum (Murris 2014; Slonimsky \& Brodie 2006; Spaull \& Hoadley 2017). Effective PD for teachers is perceived as one way of improving literacy teaching in the Eastern Cape, KZN, Limpopo and North West - areas subjected to high levels of poverty and unemployment over decades (Fleisch 2008; NEEDU 2013). Research show that children's literacy development probably can reduce poverty by enhancing positive and sustainable development, leading to better living standards (Nag, Snowling \& Asfaha 2016; Rule \& Land 2017).

Against this background this article focuses on one teacher's oral language teaching in a township school in KZN. The article explores the teacher's teaching approaches, interactions and use of resources to develop her Grade 2 learners' oral language proficiency. The main intention was to gather insights into how instructional practices shifted (or not) during the period she was enrolled with the Advanced Certificate in Teaching (ACT) programme. The research question is: How did the teacher's oral language teaching and use of resources change during the 18 months she was enrolled with ACT programme? 
The overarching concepts informing this qualitative study are effective PD interventions, teacher professional growth and the communicative approach of EFAL teaching. The principles of teaching EFAL stipulated in the language ACT programme's intended curriculum were used to analyse data collected in 2014-2015 for a PhD study (Kimathi 2017).

As the study is a case study, we cannot claim any form of generalisation of our findings. However, the insights contribute to the scholarship of teaching EFAL in a similar context or among teachers with limited access to in-service programmes. The article also offers valuable insights to the designers of language and literacy PD activities in South Africa and other similar contexts.

This case was purposively selected and pseudonyms were used to ensure confidentially of the school and the participant. Consent letters were sent to the participant in line with university and DBE ethical considerations.

\section{Conceptual understanding of professional development activities for teachers}

According to Day (1999) and Desimone (2009), PD interventions refer to learning experiences and activities intended to improve teachers' knowledge and classroom practices. Factors such as teachers' biographies and personalities, social histories, peer groups, teaching preferences, school context, quality of external activities, as well as broader policies, determine the outcomes of PD activities (Fraser et al. 2007). Dependent on the context, teachers' gains from PD activities are diverse, and range from emotional and social support to practical and cognitive knowledge which are essential to improve teaching practice (Day 2004). Professional development programmes are often offered as a particular formal initiative, underpinned by collaborative approaches for teachers to acquire new ideas, review and extend 'their commitment as change agents to the moral purposes of teaching' (Day 1999:4). This manifests in the idea that teachers learn as a result of attending specific events such as in-service programmes within a given study time (Opfer \& Pedder 2011). Often short events like workshops are perceived as collaborative interventions intended to improve teachers' knowledge and classroom practices (Lundgren, Scheckle \& Zinn 2015). However, research shows that these activities are 'quick fixes' to teacher knowledge deficiencies with no regard to the complexities of how teachers learn to teach or the contextual challenges (Brodie et al. 2002). We agree with scholars who argue that formal PD programmes may or may not lead to a teacher learning or instructional changes (Brodie et al. 2002; Lundgren et al. 2015), and acknowledge that teacher learning can happen as a result of a range of activities: informal learning, collaborative communities and structured programmes.

Clarke and Hollingsworth (2002) offer a teacher growth model that illustrates how teachers can shape their own professional growth and positive changes through reflective participation in professional programmes and in practice' (p. 948). The authors affirm that interaction of different variables within teachers' spheres determines the nature of individual professional growth and teaching changes. These conceptualisations concur with complexity theory's view of teacher learning as a dynamic process influenced by three systems (individual teacher, school context and external stimulus). These systems consist of subsystems which 'combine differently from one person to another at different times' (Opfer \& Pedder 2011:374). This means that attending a workshops or PD event is not enough to change teaching practices.

We ground our study within these complex conceptual understandings of PD and change in teachers.

\section{The stand of the curriculum on English as First Additional Language teaching}

The CAPS for EFAL at the FP encompasses four main learning areas (listening, speaking, reading and writing) with the integration of thinking, reasoning and language structure in the four areas (DBE 2011). The aim of CAPS is to strengthen the content knowledge of FP teachers and indicate how the teacher can put the theoretical knowledge into teaching practice. Specific content and preferred pedagogic practices are stipulated regarding what to teach over a year, divided into coverage per week or per term within the allocated timeframes (DBE 2011:18-23).

The FP curriculum takes an additive bilingualism approach where EFAL proficiencies are meant to be built on the prior HL proficiencies. According to this approach, HL refers to the 'mother tongue language' and assumes that learners come to school able to understand and speak their HL. The additional languages curricula assumes that learners do not necessarily have knowledge of the language. Thus, learning of EFAL is done simultaneously with the HL, with the intention to increase the learners' ability to understand, speak and write in their HL, then transferring the literacy abilities and building the new language (DBE 2011; NEEDU 2013). Studies on teaching and learning of EFAL indicate that learners who fail to master the literacy competencies in their HL struggle to learn EFAL (Sibanda \& Baxen 2018). In contrast, children growing up in high SES homes with adequate resources, develop a significant vocabulary, decoding skills and general knowledge at an early age in their HL (Crawford-Brooke 2013).

The CAPS recommends teaching oral language (listening and speaking) as a foundation of developing early graders' emergent literacy in their additional language (DBE, 211:12). Oral language is the foundation of learning a language usually acquired in a child's HL and 'consists of phonology, grammar (syntactic), morphology, vocabulary, semantics, discourse and pragmatics' (Crawford-Brooke 2013:1). The school curriculum further states that the teaching, learning and assessment of EFAL are grounded in a communicative approach. According to this approach, language acquisition is a slow holistic process mostly acquired informally. In 
teaching, language is assumed to be a tool to understand a specific message. This means that formal teaching of grammar structures is not enough for learners to develop, practise and perfect EFAL skills. Children need to hear the language, make sense of what they hear from the teacher and interact with the environment, prior to speaking the additional language to absorb the grammar and vocabulary (DBE 2011:10)

The CAPS does not offer a single approach to teaching additional languages. It supports the integration of a communicative approach with teaching of language structure (meaning and form) to improve the HL or EFAL on the learners' level of language development which concurs with language studies (Crawford-Brooke 2013; Sibanda \& Baxen 2018).

In Grade 1, teachers should expose children to numerous environmental prints in English or display familiar visuals like traffic and shopping signs and adverts to develop children's spoken language. The teachers should label some objects in both HL and EFAL to support incidental learning. Building 'word walls' and labels in the classroom continuously exposes children to simply sighting words thus building their vocabulary and grammar (DBE 2011:16). To improve learners' confidence in oral and written vocabulary, FP teachers are encouraged to facilitate more independent reading using suitable graded readers. This concurs with scholars who argue that a child with a good knowledge of vocabulary and grammar develops the coderelated skills and advanced language skills needed for comprehensive reading. However, there is no consensus on whether reading development is influenced by vocabulary acquisition only or all components of oral language (Foorman et al. 2015; Schaffler, Nel \& Booysen 2019).

What about becoming a competent user of EFAL? According to CAPS, learners must practise speaking what they learn and speak simple one-word or two-word utterances. Learners' spoken language should be standard (memorised songs, action rhymes) and phrases like 'Good morning, how are you?', 'I'm fine, how are you?' (DBE 2011:10). Gradually, as children begin to understand EFAL, they will informally start peer conversations. The teacher ought to create opportunities for all learners to develop their spoken language. For instance, using a scaffolding technique (modelling and support) where learners can act out stories told by the teacher, generate simple peer conversations and then retell the stories. As they progress, the teacher gives them more oral language tasks. For example, the teacher will introduce oral recount (e.g. telling people about what we have done), for example 'Yesterday, we went to town, then we went to the library' (DBE 2011:11). The recounting approach provides a bridge between spoken and written language at the FP. The EFAL school curriculum supports the notion that oral language acquisition among children requires effective interaction with play, songs, poems, stories, clear explanation and feedback from the teachers, small group instructions, audio-media reading, observing familiar visuals, representing thoughts graphically, critical literacies, and other creative opportunities within enjoyable and relaxed environment (Crawford-Brooke 2013; Schaffler et al. 2019; Sibanda \& Baxen 2018). If teachers develop this conceptual knowledge and effective strategies, learners can acquire and comprehend 1000-2000 contextual words by the end of Grade 2 (DBE 2011:22) and become confident English speakers.

According to this outline, the content to support FP teachers in how to teach oral language and support learners' acquisition of EFAL skills confidently, is accessible in the school curriculum but implementation of this policy is still problematic.

\section{The Advanced Certificate in Teaching programme in South Africa}

The ACT programme was offered to practising teachers who have at least a National Professional Diploma in Education (NPDE) or an equivalent after-school qualification of three years at the South Africa National Qualification Framework (NQF) Level 5. The aim of the programme was to enhance the content knowledge and competencies of the FP teachers in mathematics, HL and EFAL. The assumption is that teachers will develop an understanding of the FP curriculum and new practical knowledge to benefit their teaching practices (Hill 2010). The ACT programme at University of KwaZulu-Natal (UKZN) was specifically launched in 2013 for FP practising teachers.

The ACT programme offered by UKZN consisted of eight modules with 16 credits each, as presented in Figure 1.

Each of these modules consisted of two booklets - a Learning Guide (comprising learning content) and a Student Guide (ACT structure and assessment requirements). These modules were delivered within a minimum duration of two years or maximum of three years through a part-time mode of delivery to enhance the accessibility and individual learning pace among the participants. Apart from face-toface interactions over the weekends and holidays, interactive contextual support through classroom-based tasks was a

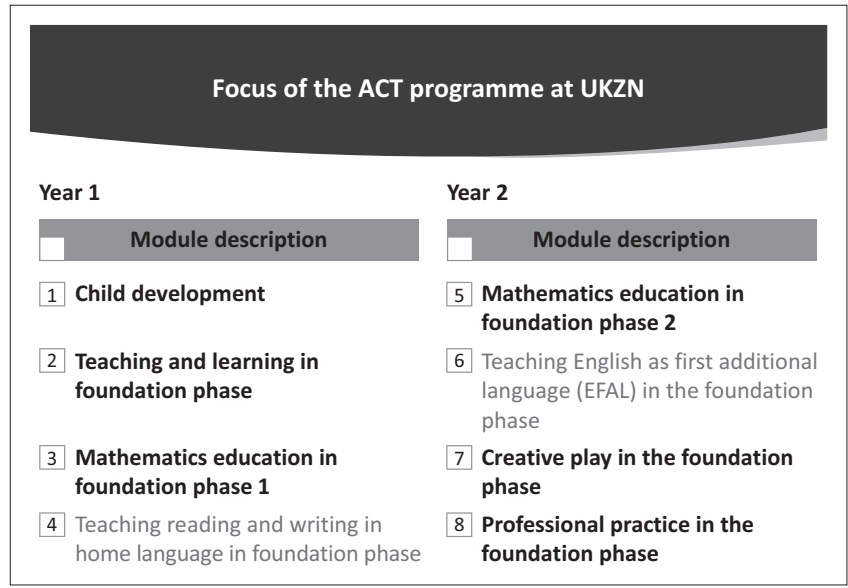

FIGURE 1: The structure of the Advanced Certificate in Teaching intended curriculum. 
TABLE 1: Advanced Certificate in Teaching programme (English as First Additional Language) intended curriculum in relation to teaching English as First Additional Language at the Foundation Phase.

\begin{tabular}{|c|c|}
\hline Principles of teaching EFAL & Indicators of good practice which were used as analytic tools \\
\hline Bilingualism consists of developing both HL and EFAL & $\begin{array}{l}\text { - Nurture bilingualism, for example use meaningful code-switching to enhance communication. } \\
\text { - Authentic learning, friendly, interesting, critical thinking, et cetera. }\end{array}$ \\
\hline $\begin{array}{l}\text { Theories that influence teaching of EFAL (formal and natural } \\
\text { approaches) }\end{array}$ & $\begin{array}{l}\text { - Teaching of grammatically correct structures of EFAL and use of formal approaches. } \\
\text { - Contextual and informal opportunities for the learners to acquire EFAL unconsciously based on Krashen's model. }\end{array}$ \\
\hline Developing vocabulary and oral sentences fluency & $\begin{array}{l}\text { - Use verbal and non-verbal resources, for example reading stories, role play, pictures, puppets, etc. } \\
\text { - Formal learning of vocabulary, for example label the classroom objects, direct instruction, theme teaching, wide } \\
\text { reading, et cetera. }\end{array}$ \\
\hline $\begin{array}{l}\text { Create and use strategies and opportunities that support } \\
\text { meaningful reading and enrich writing }\end{array}$ & $\begin{array}{l}\text { - Use balanced reading approaches: } \\
\text { - Provide opportunities for learners to manipulate words in meaningful ways } \\
\text { - Model good handwriting, pay attention to learners' scribbles or drawing }\end{array}$ \\
\hline $\begin{array}{l}\text { Print-rich learning environment to support reading, spelling } \\
\text { and writing }\end{array}$ & $\begin{array}{l}\text { - Use a range of books, pictures, creative displays, sight words: } \\
\text { - Collections that meet individual learners' specific needs } \\
\text { - Accessible reading and discussion corner or a classroom library, et cetera. }\end{array}$ \\
\hline
\end{tabular}

Source: Adopted from Kimathi, F.K., 2017, 'Professional learning of Foundation Phase teachers in the Advanced Certificate in Teaching (ACT) programme', p. 164, PhD dissertation, University of KwaZulu-Natal, Durban

EFAL, English as First Additional Language; HL, Home Language.

convenient learning method. There has not been a great deal of systematic research to track teachers' gains from similar programmes (Mukeredzi, Bertram \& Christiansen 2018). Understanding teachers' gains from formal programmes that impact their teaching is crucial for enhancement of other PD interventions. This article also aims to contribute to this field.

Table 1 offers the principles of teaching EFAL highlighted in the ACT programme intended curriculum. The authors used the principles to measure the teacher's pedagogical shifts

\section{Research design}

This study takes a qualitative approach which is typical of descriptive case studies (Yin 2009) to understand one teacher's instructional practices of developing oral language with Grade 2 learners. The study also reflects on the teacher's understanding and experiences on how the ACT programme influenced her teaching practice. We are aware that case studies are criticised in relation to generalisability. However, the strengths of a case consist in its ability to generate a rich description using multiple data within a specific setting (Simons 2009; Yin 2009). Therefore, single cases like our study can be realised in similar contexts or insights, and in accumulation may form the basis from which longitudinal studies can draw.

\section{The study context}

The context of the study is KZN province with a large rural population. In particular, $16.4 \%$ of KZN's population has little or no education (Stats SA 2018) to contribute meaningfully towards the literacy development of their own children or support the teaching process (Rule \& Land 2017). The province has consistently yielded some of the lowest ANA literacy scores in the country (DBE 2016).

The school is located in the middle of a township (formerly a black residential area) over the undulating green slopes of eThekwini municipality, $65 \mathrm{~km}$ from Pietermaritzburg. It is no-fee public school with permanent buildings and basic classroom resources such as chalkboards, teaching aids and learners' desks and seats. Most of the learners come from a poor socio-economic background and rely on the national school feeding programme which boosts school attendance. IsiZulu is the medium of instruction in the FP and the HL of approximately $99 \%$ of the FP learners.

\section{The participant}

Lisa (pseudonym) is a black African female in her mid-40s, who completed high school in 1990. Lisa has been teaching in the township school for 16 years, 10 years as a Grade 3 teacher before joining Grade 2. On a part-time basis she acquired her first professional qualification, the NPDE and subsequently completed a short course on Life Orientation teaching skills in 2010. During the data collection period in 2014-2015, Lisa's classes consisted of 42 and 44 learners. Lisa claimed to have attended more than five DBE workshops in 2011-2013 on how to teach EFAL. From our observations and interactions, Lisa portrayed the image of a self-motivated and creative goal-achiever. This was evidenced by the self-designed posters, colourful and well-arranged learning space, and a variety of posters, most of them labelled in both HL and EFAL. The fact that she designed and provided funds to sew book bags for all her learners reflects an innovative and selfmotivated personality.

\section{Data collection}

The data examined was part of a doctoral study which explored the professional learning of three purposively selected Grade 2 teachers. For this article, Author 1 revisited the PhD data for an in-depth understanding of one teacher's experiences and implementation. The aim was to understand how the ACT programme may have contributed to any pedagogic shifts. Therefore, only one teacher's (Lisa) data was re-examined to explore her instructional practices of teaching oral language during EFAL lessons. Data were collected over 18 months consisting of six classroom videos, interviews and field notes (in February 2014, August 2014 and October 2015).

\section{Data analysis}

This article uses the principles of teaching EFAL at the FP as the analytic tool to comprehend the pedagogical shifts and use of resources. The principles are espoused in the ACT 
programme's intended curriculum as summarised in Table 1. Two kinds of analysis were carried out to understand the oral language teaching and how the ACT programme may have contributed to any changes in instructional practices video recorded or observed in class.

Firstly, Lisa's story was generated after careful reading of video transcripts and corroborated by what Lisa said during the interviews and observation field notes. Lisa verified the story and alterations were made. The narrative illuminated Lisa's knowledge and skills that she claimed to have learnt from the ACT programme about oral language teaching and how the programme impacted her teaching. Secondly, to analyse Lisa's oral language teaching and use of resources, we created specific episodes of the lessons from the video transcripts which were deductively scored against a set of indicators. The $12 \mathrm{key}$ indicators (presented in Table 1) were generated from the five principles of teaching EFAL according to the ACT programme. We used the indicators to make sense of the teacher's talks, interaction with the learners, peer conversations and use of resources during the lesson (see Kimathi 2017 for details).

\section{Key findings about Lisa's English as First Additional Language pedagogic practices}

This section presents findings to illustrate teacher Lisa's oral language teaching and use of resources during the period of her enrolment with the ACT programme at UKZN in 2014-2015. Firstly, we offer a short summary of a phonics lesson which was observed, and audio recorded on 12 February 2014 (at the beginning of the programme). This was because it was not possible to capture an oral language lesson in Term 1 due to CAPS content prescription and classroom logistics. Secondly, two excerpts of Lisa's oral language teaching which were video recorded in September 2014 and October 2015 are offered.

\section{Lesson 1 - 14 February 2014}

Lisa used the chalkboard to write simple English words. She predominantly read the sounds and simple English words written on the chalkboard and the learners repeated whatever she said. After a period of $20 \mathrm{~min}$ of this strategy, Lisa instructed the learners in HL only to copy the words in their exercise books. The teacher monitored the learners as they sluggishly did the activity. The execution of the lesson was inconsistent with a slow pace. Some learners did not have pencils or exercise books and the teacher had to offer the few pencils in the cupboard to some learners. Informal conversation with Lisa revealed the DBE had not delivered the workbooks and other learning resources. She also highlighted that poor parents did not buy stationery for their children. In addition, the phonic interactive resources were few in the school. These resources were donated by the Soul Action (educational nongovernmental organisations [NGO] initiative) who had an onsite coaching programme for the FP teachers from 2013. There were only three posters (from the previous year) in the classroom and two were labelled in HL. A cupboard with some pencils, chalk and books stood next to the teacher's table. The learners were seated in rows within the crowded classroom.

The lesson displayed implicit instruction and limited tasks (isolated single word oral reading). Learners' choral responses and repeating whatever the teacher said depicted ineffective strategies of teaching and limited opportunities for active interaction. The choral responses portrayed deficient teaching of phonics and little understanding by the learners. The words and phonics written on the board were of low cognitive demand. These kinds of classroom interactions were consistently overheard by the researcher across the other FP classroom block.

We now offer also two excerpts (Box 1 and Box 2) of Lisa's oral language teaching which were video recorded in September 2014 and October 2015. Since we did not get an opportunity to video record an oral language lesson earlier in the year, Lesson 2 was observed and recorded when the ACT the programme was in progress in September 2014. Lisa's class consisted of 42

BOX 1: Lesson 2.

Date: 03 September 2014

Topic: Oral vocabulary

Duration: $35 \mathrm{~min}$

Class: $2 \mathrm{~B}$

Classroom was colourful with a variety of colourful pictures, charts for the three subjects and familiar supermarket advertisements. The notice board had neatly written classroom rules and routines. Department of Basic Education workbooks were well arranged at back of the crowded room. The learners were seated in groups as the teacher moved between the groups to distribute the miniboards, chalk, small dusters and flip-cards (with phonics). She introduced the lesson in English and repeated the instructions in isizulu explicitly.

Episode 1 (20 $\mathrm{min}$ )

T: I will say a word and you gonna repeat after me but first I will show you the picture and you tell me the word. Look at this picture. (large self-drawn picture of a fist with a 'thumb' sticking out)

L1: Hand.

T: Look at this picture nicely. (Lisa moving slowly among the groups)

L2: Hand.

L3: Sharp. (Lisa kept moving and made sure every child can see the picture).

T: OK, this is a hand, but we are looking at this (shows her thumb). What is this in isizulu? (learners responded positively). This is called $\boldsymbol{a}$ thumb in English. (The word 'thumb' was repeated three times by the learners. Other words discussed and pasted on the chalkboard - thousand, thief and thermometer.)

T: What sound can you hear in this word? (She asked the class for one word at a time, then reviewed the sounds $\boldsymbol{t}$, $\boldsymbol{h}$ and th. She also incorporated the numeracy concepts to emphasise the sound th. The teacher had created a 'fan-shaped' flip-card with different sounds which learners easily flipped and responded to the phonic questions.)

Episode 2 (15 $\mathrm{min})$

Learners were given clear instruction and a demonstration on how to draw a rectangle frame on their miniboards. Each child wrote the phonemes of the words (based on the onset and rhyme) on their small boards (as shown on the chalkboard) and held it up for the teacher to see. She explained the location of the different sounds on the frame and learners repeated what she said (choral responses dominated). Learners seemed familiar with the activity. The teacher applauded correct responses and did not tolerate any distraction. Learners seemed excited because the activity was easy, and they had an opportunity to use the miniboards instead of exercise books. Learners did not have an opportunity to write sentences using their prior knowledge or word-wall labels in the print-rich classroom environment. 
BOX 2: Lesson 3.

\section{Date: 28 October 2015}

Topic: Listening and Speaking

Duration: $45 \mathrm{~min}$

Class: $2 B$

The classroom was colourful with a diverse display of colourful pictures, charts for all learning areas, displays of real objects labelled in both home language (isizulu) and additional language (English), familiar adverts and learners' creative drawings. The notice board had neatly written classroom rules and routines. Department of Basic Education workbooks and extra books were well arranged on either side of the classroom. The learners were seated in groups and relaxed.

\section{Episode 1 (15 $\mathrm{min})$}

Lisa unveiled a self-drawn picture mounted on a wooden stand and steadily walked around the class with the picture to ensure all of the children were able to clearly see the picture. Lisa mounted it back on the stand and then stimulated the learners into a conversation. Lisa consistently encouraged individual responses and corrected responses, and were applauded by the whole class. Part of the conversation went as follows:

T: What is happening in this picture?

L1: It is a beach (responded in isizulu)

T: Why do you think it's a beach?

L2: Water

T: (She described the picture) This is a beach; we can see a boy playing with a bucket with sand.

(Chorus) Yes teacher

T: When do people go to the beach?

L3: Christmas day.

T: Good, it's nice to go to the beach on Christmas day!

L2: December

L2: December
T: Yes, during the December holiday. Now tell me why we go to the beach during the December?

T: Yes, Hot

T: (wrote the word hot on the chalk board). Yes, we go when it's hot. The days in December are sunny and we feel hot. So, when we want to feel cool, we go to the beach

(discussion continued)

Episode 2 (15 $\mathrm{min}$ )

The teacher gave the learners 3 min to study a typical detailed tourist beach poster. She described the different activities on the beach and followed a similar sequence for this

The teacher gave the learners $3 \mathrm{~min}$
episode.

T: What is the colour of the water?

T: Blue and there are many people, women, men, boys. Am I clear? (learners repeated)

T: What are the children building? The children are building a sandcastle.

(class repeated) The children are building a sandcastle.

T: What is to build?

L4: (in isizulu) To build a house.

T: Good, who is building? The children are building the sandcastle. (learners repeated)

L5: (in isizulu) The children are buying ice-cream.

Episode 3 (15 $\mathrm{min})$

Learners had an opportunity to colour the worksheets (version of the poster in A4).

learners in this year. Lesson 3 was observed and recorded when the ACT programme was ending in October 2015. Lisa's class had 44 learners in this particular year. This means these two vignettes describe different Grade 2 learners.

According to the principles of teaching EFAL in this episode, Lisa in lesson 2 sustained a good balance between HL and EFAL and used them appropriately. She explicitly introduced the lesson in EFAL and repeats in isiZulu for clarity. She kept reminding the learners to speak in English throughout the lesson. Lisa had prepared the resources to use in contrast to the phonic lesson which we observed in February 2014, when there were no resources apart from the chalkboard.

Meaningful repetition, familiar visuals and mutual communication were evidenced when explaining the sounds of the letters, word patterns, and rhymes. These were meaningful strategies to support word identification. She was able to integrate the teaching of vocabulary with phonics, explicit teaching of the words but within low cognitive demand.

Lisa provided clear feedback to the whole class in response to individual errors (focus on the 'thumb' not the 'hand'). Learners were actively searching for different sounds on the flip-cards and writing phonics on the mini boards. Thus, the teacher provided reasonable opportunities for learners to speak in English, listen to teachers' simple instructions and used familiar strategies to develop their oral vocabulary. These methods concur with the principles of bilingualism and strategies of building vocabulary among the young children. We argue that Lisa presented a moderate integration of formal teaching and Krashen's natural theory to acquiring an additional language, which had been taught in the ACT programme.

The third of Lisa's oral language lessons was recorded in October 2015 with 44 Grade 2 learners. This was as the end of the two-year ACT programme.

Lesson 3 illustrates a gradual instructional shift with more teacher-learner interactions, an increase in teacher's confidence, more integration of resources when teaching, and learners were offered more opportunities to participate.

For example, Lisa in a sequenced manner used repetition effectively most of the time, an oral recount approach and questioning technique to encourage learners to speak and interpret the various activities in the two episodes. Interactive discussion covered what, who, why and when aspects within their level of understanding of EFAL. She was also able to introduce different words which were familiar to the learners in episode 2. She used repetition and questioning technique to guide learners to build short sentences and corrected learners' errors or misconceptions in this episode. The learners listened and repeated the sentences or the words. Learners gained some confidence evidenced by their participation in short oral conversations with the teacher. According to Lisa some of the teaching techniques were modelled by the Soul Action programme during a coaching session for the FP teachers in the school.

We argue that Lesson 3 indicates that Lisa had gained more conceptual knowledge about teaching EFAL and was able to 
enact this knowledge practically in the classroom. She was able to blend the formal teaching of vocabulary and enhanced purposeful listening and authentic speaking among the enthusiastic children. She monitored the learning tasks, promised to display their works the next morning in the classroom (lesson 3). The next day, the colourful worksheets were displayed. According to the ACT intended curriculum and CAPS, at Grade 2, learners should be more exposed to effective interaction with play, songs, poems, stories, small group instructions, observing familiar visuals, representing thoughts graphically and other creative opportunities within an enjoyable and relaxed environment which Lisa tried to create during this lesson.

The interviews and field notes data revealed Lisa had a better understanding of how to make use the print-rich environment and resources at the end of the ACT programme in October 2015. Resources such as strategy games, sight words, puzzles, posters, mini boards, plus consumables had been provided and modelled by the Soul Action programme. Learners were seated in small groups which was a change from the row seating arrangement observed in February 2014. 'The reason why I changed the seating arrangement again [2015], so that the learners can see each other and share things', Lisa said. This also created good peer interaction and teamwork as learners mingled freely and shared the crayons in lesson 3. Lisa also said that she learnt problem-solving techniques from ACT and Soul Action programmes. This motivated her to tailor 44 book bags to create space on the learners' tables. The blue well-tailored bags with the extra books acted as 'lumbar support cushions' on each child's little chair.

\section{Discussion}

We contend that the three lessons described above are indicative of a shift in oral language teaching, a shift in using resources and creating a good learning environment. This was measured against Lisa's application of principles of teaching EFAL (espoused in ACT module 6) with two different classes of learners in 2014 and 2015.

To recap, Lisa's oral vocabulary lesson 2 (September 2014) was observed seven months after she had enrol in the ACT programme. She predominantly used a question-andresponse technique, implicit instructions, repetition of familiar words, but learners did not have confidence to communicate in English. The choral responses were in HL and portrayed deficiency in oral vocabulary and concentration on letter-sound relationships with little comprehension by the learners. These kinds of literacy teaching were consistently overheard by the researcher from the other FP classroom block.

With reference to lesson 3, these Grade 2 learners seemed to have gained more confidence and responded to the teacher's prompts and constructed short sentences by September 2015. Significant improvement in the quality of and increased frequency in Lisa's responses to learners' errors and misconceptions was observed between lesson 2 and lesson 4 .
There also seemed to be a shift in Lisa's classroom environment which became more print-rich in 2015 compared to the data collected in 2014. The print-rich classroom conformed to the CAPS minimum requirements and supported the EFAL principles privileged in the ACT intended curriculum in terms of the storage of resources, recognition of a reading corner and a variety of readers. Having a well-structured print-rich classroom environment is vital, especially in disadvantaged contexts. However, to improving learner's oral vocabulary depends on consistency and how teachers meaningfully use the resources (Hill 2010; Stoffelsma 2019). Lisa progressively integrated the picture and charts and increased interactive discussions in lesson 3 in 2015.

While we argue that although Lisa's practice had changed, there is still room for improvement. For example, the learners in lesson 3 engaged in a creative colouring task rather than a task which would support oral competency, while the task was also at a low cognitive level. The lesson also did not encompass any opportunities for learners to write sentences. According to CAPS, the teacher needs to extend learners' writing abilities in Grade 2 and Grade 3 (DBE 2011). Lisa claimed that the objective of lesson 3 was to develop learners' proficiency in oral English and that sentence writing was planned for the next lesson. This implies that Lisa was very aware of the CAPS requirements although writing opportunities were limited in the lessons observed (Kimathi \& Bertram 2019).

We argue that the instructional shifts observed were gradual and influenced by a range of factors that cannot be attributed only to the ACT. Firstly, Lisa's commitment to her own personal growth together with her peers even before enrolling in the ACT programme seemed rooted in her belief that teaching is her vocation. 'Teaching the young kids is my calling', she noted. Such moral obligation requires a self-driven and enthusiastic disposition which was confirmed during the August 2014 interview. Lisa indicated she had implemented subject advisors' new ideas about the CAPS document and DBE workbooks during the DBE workshops in 2013-2014. She also engaged with other initiatives that offered collaborative platforms to reflect on their teaching practices, discuss context challenges and possible solutions.

Lisa indicated that ACT programme offered her and her peers opportunities to compare their teaching practices and to obtain new knowledge. Teachers were able to use new knowledge and understanding as a mirror to reflect on their experiences, linking them to personal imagination and needs. Lisa engaged with other external professional development aids, such as DBE workshops whose mission was to support the interpretation and coverage of CAPS. The Action Soul coaching programme modelled teaching strategies and offered a range of resources to be used by the FP teachers. That means that Lisa's pedagogical shifts cannot be attributed to the ACT programme only. 
Lisa's school has a supportive school management team (SMT), in which the deputy principal consistently interacted with the researchers during the data collection phases. Lisa confirmed that the SMT provided teaching resources, regular teacher assessment, encouraged collaboration and organised substitute teachers during the ACT programme face-to-face learning sessions. This kind of school support concurs with the NEEDU report that 'school SMTs should structure and lead systematic learning opportunities for teachers, through regular discussions on matters of curriculum, pedagogy and assessment' (NEEDU 2014:58).

Results of the analyses clearly indicate the interplay between the ACT programme, coaching from other external PD activities in the context, Lisa's commitment and effort, appropriate teaching resources, compliance with CAPS and school support, together, impacted on Lisa's instructional practices and professional learning. These echo international findings that a teacher's ability to effectively implement new knowledge is strongly dependent on their beliefs, cognitive level, resilience, motivation, professional identity, values, and commitment to their professional learning and service, as well as on the school context in which they teach and the nature of the professional development intervention (Day \& Gu 2007; Korthagen 2017; Opfer \& Pedder 2011). However, to fully understand the relationship between these factors requires further research.

\section{Final thought}

Although our findings were drawn from one case, the findings illuminate how teaching practice may change within the constraints of a township school in South Africa. Thus, understanding such cases, offers insights to PD providers and school communities, purposed to improve the teaching of various components of teaching EFAL at the FP.

The ACT programme provided Lisa with knowledge and principles about teaching EFAL, and the data shows that changing teaching practices is a slow process influenced by an interplay of intrinsic and extrinsic factors. The key factors in this case include teacher commitment to learn new concepts and execute them successfully, school support and coaching of teachers in their contexts, and subject-oriented PD activities for theoretical and procedural knowledge. Outside of the PD programme, this case study shows that change in teaching practice is influenced by the context, teachers' beliefs and attitudes. Overall, the implication of our findings relates to Piper et al.'s (2018) suggestions that collaboration between effective PD activities, appropriate resources, technology and structured coaching are a suitable model to achieve sustainable language and literacy teaching in the sub-Saharan context.

\section{Acknowledgements}

The authors would like to extend their sincere appreciations to the school, the Grade 2 teacher and the learners who participated and allowed us to use the data collected for this study.

\section{Competing interests}

Both authors participated in the preparation of the manuscript and have no competing interests to declare.

\section{Authors' contributions}

F.K.K. is a post-doctoral fellow and the primary researcher who is reporting on her PhD study. She is also the primary writer of the article. C.B. is the supervisor, host of this fellowship and has contributed to the article by providing guidance regarding focus and structure.

\section{Ethical consideration}

The participant signed consent forms and permission was granted by KZN Department of Basic Education (Ref $1 / 102 / 2014)$ and UKZN Higher Degrees and Ethics Committee awarded ethical clearance (Ref. HSS/0098/014D).

\section{Funding information}

This research did not receive any specific grant from any funding.

\section{Data availability statement}

Data sharing is not applicable to this article as no new data were created or analysed in this study.

\section{Disclaimer}

The views and opinions expressed in this article are those of the authors and do not necessarily reflect the official policy or position of any affiliated agency of the authors.

\section{References}

Adler, J. \& Reed, Y., 2000, 'Researching teachers' "take-up" from a formal in-service professional development programme', Journal of Education 25, 192-226.

Bertram, C., 2011, 'What does research say about teacher learning and teacher knowledge? Implications for professional development in South Africa', Journal of Education 52(5), 26.

Blease, B. \& Condy, J., 2014, 'What challenges do foundation phase teachers experience when teaching writing in rural multigrade classes?', South African Journal of Childhood Education 4(2), 36-56. https://doi.org/10.4102/sajce.v4i2.203

Brodie, K., Lelliott, A. \& Davis, H., 2002, 'Forms and substance in learner-centred teaching: Teachers' take-up from an in-service programme in South Africa', Teaching and Teacher Education 18, 541-559. https://doi.org/10.1016/S0742-051X(02)00015-X

Cilliers, L. \& Bloch, C., 2018, 'A reading project to improve literacy in the foundation phase: A case study in the Eastern Cape', Reading \& Writing 9(1), 1-7. https://doi. org/10.4102/rw.v9i1.167

Clarke, D. \& Hollingsworth, H., 2002, 'Elaborating a model of teacher professional growth', Teaching and Teacher Education 18(8), 947-967. https://doi.org/10.1016/ S0742-051X(02)00053-7

Crawford-Brooke, E., 2013, The critical role of oral language in reading for Title I students and English language learners, Lexia, a Rosetta Stone Company, Arlington, VA.

Day, C., 1999, Developing teachers: The challenges of lifelong learning, Routlegde Falmer Press, London.

Day, C., 2004, A passion for teaching, Routledge Falmer, London.

Day, C. \& Gu, Q., 2007, 'Variations in the conditions for teachers' professional learning and development: Sustaining commitment and effectiveness over a career', Oxford Review of Education 33(4), 423-443. https://doi.org/10.1080/03054980701450746

Department of Basic Education, 2011, Curriculum and assesment policy: First additional language for Grade 1-3, Foundation Phase, Government Printer, Pretoria.

Department of Basic Education (DBE) South Africa, 2016, Education Statistics in South Africa: 2014, Government Printer, Pretoria. 
Department of Basic Education and Department of Higher Education and Training (DBE \& DHET), South Africa, 2011, Integrated strategic planning framework for teacher education and development in South Africa 2011-2015, Government teacher education

De Clercq, F. \& Shalem, Y., 2014, 'Teacher knowledge and employer-driven professional development: A critical analysis of the Gauteng Department of Education programmes', Southern African Review of Education 20(1), 129-147.

Desimone, L.M., 2009, 'Improving impact studies of teachers' professional development: Toward better conceptualisations and measures', Educational Researcher 38(3), 181-199. https://doi.org/10.3102/0013189X08331140

Fleisch, B., 2008, Primary education in crisis: Why South African schoolchildren underachieve in reading and mathematics, Juta \& Co, Ltd, Cape Town.

Fleisch, B., 2016, 'System-wide improvement at the instructional core: Changing reading teaching in South Africa', Journal of Educational Change 17(4), 437-451. https://doi.org/10.1007/s10833-016-9282-8

Foorman, B.R., Herrera, S., Petscher, Y., Mitchell, A. \& Truckenmiller, A., 2015, 'The structure of oral language and reading and their relation to comprehension in Kindergarten through Grade 2', Reading and Writing 28(5), 655-681. https://doi. org/10.1007/s11145-015-9544-5

Fraser, C., Kennedy, A., Reid, L. \& Mckinney, S., 2007, 'Teachers' continuing professional development: Contested concepts, understandings and models', Journal of Indevelopment: Contested concepts, understandings and models', Journal of In-
Service Education 33(2), 153-169. https://doi.org/10.1080/13674580701292913

Hill, A., 2010, Advanced Certificate in Teaching (ACT) Foundation Phase, ACT 6 : Teaching English as an additinal language in FP, University of KwaZulu-Natal, School of Education, Pietermaritzburg Campus.

Hoadley, U., 2012, 'What do we know about teaching and learning in South African primary schools?', Education as Change 16(2), 187-202. https://doi.org/10.1080/ 16823206.2012.745725

Howie, S.J., Combrinck, C., Roux, K., Tshele, M., Mokoena, G.M. \& McLeod, P.N., 2017 PIRLS literacy 2016: South African highlights report (Grade 4), Centre for Evaluation and Assessment (CEA), Pretoria.

Kimathi, F.K., 2017, 'Professional learning of Foundation Phase teachers in the Advanced Certificate in Teaching (ACT) programme', PhD, University of KwaZuluNatal, Durban.

Kimathi, F.K. \& Bertram, C.A., 2019, 'How a professional development programme changes early grades teachers' literacy pedagogy', South African Journal of Childhood Education 9(1), 1-10. https://doi.org/10.4102/sajce.v9i1.554

Korthagen, F., 2017, 'Inconvenient truths about teacher learning: Towards professional development 3.0.', Teachers and Teaching 23(4), 387-405. https://doi.org/10.108 development 3.0.', Teachers
$0 / 13540602.2016 .1211523$

Kotze, J., Fleisch, B. \& Taylor, S., 2019, 'Alternative forms of early grade instructional coaching: Emerging evidence from field experiments in South Africa', International Journal of Educational Development 66, 203-213.

Lundgren, B.O., Scheckle, E. \& Zinn, D., 2015, 'Teachers' professional development: Awareness of literacy practices', South African Journal of Education 35(1), 1-11. https://doi.org/10.15700/201503062347

Meyer, S. \& Abel, L., 2015, 'Hastening slowly: Insights about teacher development from an evaluation of courses at the WCED's Cape Teaching and Leadership Institute', Journal of Education 61, 115-146.

Mukeredzi, T., Bertram, C. \& Christiansen, I., 2018, 'Investigating teacher learning from a university programme for Foundation Phase teachers', South Africa Journal of Childhood Education 8(1), 1-10. https://doi.org/10.4102/sajce.v8i1.524
Murris, K., 2014, 'Philosophy with children as part of the solution to the early literacy education crisis in South Africa', European Early Childhood Education Research Journal 24(5), 652-667. https://doi.org/10.1080/1350293X.2014.970856

Murris, K.S. \& Thompson, R., 2016, 'Drawings as imaginative expressions of philosophical ideas in a Grade 2 South African literacy classroom', Reading \& Writing-Journal of the Reading Association of South Africa 7(2), 1-11. https://doi. org/10.4102/rw.v7i2.127

Nag, S., Snowling, M.J. \& Asfaha, Y.M., 2016, 'Classroom literacy practices in low-and middle-income countries: An interpretative synthesis of ethnographic studies', Oxford Review of Education 42(1), 36-54. https://doi.org/10.1080/03054985.201 5.1135115

National Education Evaluation and Development Unit (NEEDU), 2013, South African National Report 2012: The state of literacy teaching and learning in the Foundation Phase, Government Printer, Pretoria.

National Education Evaluation and Development Unit (NEEDU), 2014, South African National Report 2013: Teaching and learning in rural primary schools, Government Printer, Pretoria.

Opfer, V.D. \& Pedder, D., 2011, 'Conceptualising teacher professional learning', Review of Educational Research 81(3), 376-407. https://doi.org/10.3102/0034654311413609

Piper, B., Zuilkowski, S.S., Dubeck, M., Jepkemel, E. \& King, S.J., 2018, 'Identifying the essential ingredients to literacy and numeracy improvement: Teacher professional development and coaching, student textbooks, and structured teachers' guides', World Development 106, 324-336. https://doi.org/10.1016/j.worlddev.2018. 01.018

Pretorius, E.J., 2014, 'Supporting transition or playing catch-up in Grade 4? Implications for standards in education and training', Perspectives in Education 32(1), 51-77.

Prinsloo, C.H., Ramani, E., Joseph, M., Rogers, S., Mashatole, A., Lafon, M. et al., 2015 An inter-province study of language and literacy paradigms and practices in Foundation Phase classrooms in Limpopo and Gauteng, HSRC, Pretoria.

Rule, P. \& Land, S., 2017, 'Finding the plot in South African reading education', Reading \& Writing 8(1), 1-8. https://doi.org/10.4102/rw.v8i1.121

Schaffler, D., Nel, M. \& Booysen, R., 2019, 'Exploring South African Foundation Phase teachers' understanding, skills and training needs in the teaching of phonologica awareness', The Language Learning Journal 35(1), 1-14. https://doi.org/10.1080/ 09571736.2019 .1655585

Sibanda, J. \& Baxen, J., 2018, 'Third-Grade English Second Language teachers' vocabulary development practices', South African Journal of Childhood Education 8(1), 1-9. https://doi.org/10.4102/sajce.V8i1.545

Simons, H., 2009, Case study research in practice, Sage, Los Angeles, CA.

Slonimsky, L. \& Brodie, K., 2006, 'Teacher learning: Development in and with social context', Southern African Review of Education 12(1), 45-62.

Spaull, N. \& Hoadley., U., 2017, 'Getting reading right: Building firm foundation', in L. Jamieson, L. Berry \& L. Lake (eds.), South African child gauge, pp. 77-83, Children's Institute, University of Cape Town, Cape Town.

STATS SA, 2018, Poverty on the rise in South Africa, viewed 12 October 2018, from http://www.statssa.gov.za/?p=10334.

Stoffelsma, L., 2019, 'English vocabulary exposure in South African township schools: Pitfalls and opportunities', Reading \& Writing 10(1), 1-10. https://doi.org/ 10.4102/rw.v10i1.209

Yin, R.K., 2009, Case study research, Sage, Los Angeles, CA. 